\title{
Gender difference in survival of resected non-small cell lung cancer: Histology-related phenomenon?
}

\author{
Jee Won Chang, MD, ${ }^{a}$ Hisao Asamura, MD, ${ }^{\mathrm{b}}$ Riken Kawachi, MD, ${ }^{\mathrm{b}}$ and Shun-ichi Watanabe, $\mathrm{MD}^{\mathrm{b}}$
}

Objective: It remains controversial whether there is a gender difference in survival of patients with resected nonsmall cell lung cancer.

\begin{abstract}
Methods: We retrospectively analyzed 2770 patients (1689 men and 1081 women) with non-small cell lung cancer who underwent pulmonary resection between 1995 and 2005 at the National Cancer Center Hospital, Tokyo. A gender difference in survival was studied in all patients, in those divided according to histology or pathologic stage, and in propensity-matched gender pairs.

Results: There were no differences in background, such as preoperative pulmonary function, operation procedures, or operative mortality. The proportions of adenocarcinoma and pathologic stage $\mathrm{I}$ in women were greater than those in men $(93.6 \%$ vs $61.7 \%$ and $71.4 \%$ vs $58.6 \%$, respectively $)(P<.001)$. Overall 5 -year survival of women was better than that of men $(81 \%$ vs $70 \%, P<.001)$. In adenocarcinoma, the overall 5-year survival for women was better than that for men in pathologic stage I $(95 \%$ vs $87 \%, P<.001)$ and in pathologic stage II or higher $(58 \%$ vs $51 \%, P=.017)$. In non-adenocarcinoma, there was no significant gender difference in survival in pathologic stage I $(P=.313)$ or pathologic stage II or higher $(P=.770)$. The variables such as age, smoking status, histology, and pathologic stage were used for propensity score matching, and survival analysis of propensity score-matched gender pairs did not show a significant difference $(P=.69)$.
\end{abstract}

Conclusion: Women had better survival than men; however, there was no survival advantage in propensitymatched gender pairs. A gender difference in survival was observed only in the adenocarcinoma subset, suggesting pathobiology in adenocarcinoma in women might be different from that of men.

Most studies on gender-associated differences in lung cancer have found that women have several characteristics that are different from those in men, such as younger age at presentation, larger proportions of nonsmokers and early-stage diseases, and predominance of adenocarcinoma. ${ }^{1-6}$ However, the influence of female gender on survival remains controversial because it has been insisted that gender is not a significant prognostic factor in non-small cell lung cancer (NSCLC), although gender has been associated with smoking exposure, stage, histologic subtype, and therapeutic management. ${ }^{7,8}$

We believe that a unique analysis with a large database may help to clarify the influence of gender on survival. The purpose of this study is to explore gender differences in clinical characteristics and survival based on a retrospective analysis of patients with NSCLC who had undergone lung resection in a single institute during an 11-year period.

From the Cheju National University Hospital, School of Medicine, Cheju National University, ${ }^{\mathrm{a}}$ Jeju, South Korea; and Division of Thoracic Surgery, National Cancer Center Hospital, ${ }^{\mathrm{b}}$ Tokyo, Japan.

Received for publication March 23, 2008; revisions received Aug 25, 2008; accepted for publication Sept 12, 2008.

Address for reprints: Hisao Asamura, MD, Division of Thoracic Surgery, National Cancer Center Hospital 1-1, Tsukiji 5-chome, Chuo-ku, Tokyo 104-0045, Japan

(E-mail: hasamura@ncc.go.jp).

J Thorac Cardiovasc Surg 2009;137:807-12

$0022-5223 / \$ 36.00$

Copyright (c) 2009 by The American Association for Thoracic Surgery

doi:10.1016/j.jtcvs.2008.09.026

\section{MATERIALS AND METHODS}

From January 1995 to December 2005, 2800 patients underwent lung resection for primary lung cancer at the National Cancer Center Hospital, Tokyo. Among these, 2770 patients (1689 men and 1081 women) who underwent lung resection for NSCLC were reviewed retrospectively. This study was approved by the institutional review board.

Preoperative evaluation was done by means of history and physical examination, posteroanterior and lateral chest radiographs, and blood tests, including complete blood count and serum chemistries. Computed tomography scans of the chest and upper abdomen (including the liver and adrenal glands) were checked routinely. Bone scintigraphy and brain imaging were performed in cases of suspicious symptoms. A pulmonary function test and electrocardiography were checked routinely. Quantitative pulmonary ventilation and perfusion scan were performed in patients with marginal pulmonary function. The evaluation of chronic diseases and consultation with the corresponding physicians depended on the patients' conditions.

Patients with clinical stages I and II and selected cases of stage IIIA underwent lung resection via thoracotomy. Basically, neoadjuvant preoperative therapy was not performed except for recent cases of superior sulcus tumor. Patients with $\mathrm{N} 2$ disease that was detected intraoperatively received postoperative adjuvant therapy. All patients were staged on the basis of the International Union Against Cancer TNM Classification of Malignant Tumors staging system published in $1997,{ }^{9}$ and tumor histology was described according to the World Health Organization classification. ${ }^{10}$ For tumors of adenocarcinoma with a greatest dimension of $2 \mathrm{~cm}$ or less, Noguchi and colleagues' classification ${ }^{11}$ was used to describe the histopathologic details. Types A and B correspond to bronchoalveolar carcinoma in the World Health Organization classification, whereas type $\mathrm{C}$ corresponds to adenocarcinoma with mixed subtypes, including bronchoalveolar carcinoma and invasive adenocarcinoma. Types D, E, and F correspond to invasive solid, acinar, and papillary adenocarcinoma, respectively.

Follow-up was achieved through periodic visits to the outpatient clinic until the present time or patient's death. Operative mortality was defined as death during hospitalization for lung resection or within 30 days of operation. 


\section{Abbreviation and Acronym \\ NSCLC $=$ non-small cell lung cancer}

The chi-square test was used to evaluate the significance of observed differences in the proportions of patients in the various outcome categories. Survival was measured from the date of operation, and the median survival was calculated and plotted according to the Kaplan-Meier method. Differences in survivals between groups were compared with the log-rank test.

For balanced assignment of the included patients to correct gender confounding in survival, propensity score matching was used. The variables such as age (continuous), smoking status (ever or never), histologic types (adenocarcinoma, squamous cell carcinoma, large cell carcinoma, or others), and pathologic stages (I, II, III, or IV) were used. These were selected on the basis of their significant difference between both genders (Table 1). A coefficient that was calculated by logistic regression analysis was multiplied to each variable, and the sum of these values were the propensity score for individual patient. ${ }^{12}$ Gender pairs with equivalent propensity score were selected by a 1-to-1 match. All survival comparisons and analyses were performed using SigmaPlot (Systat Software Inc, San Jose, Calif).

\section{RESULTS}

\section{Clinical Features, Histology, and Pathologic Staging}

The clinical characteristics of 2770 patients are summarized in Table 1. The distribution of histologic subtypes was significantly different between the 2 genders: There was more adenocarcinoma $(93.6 \%$ vs $61.7 \%, P<.001)$ and less squamous cell carcinoma $(4.1 \%$ vs $30.3 \%, P<$ $.001)$ in women. The distribution of pathologic stages showed a statistically significant gender difference in that women had a disproportionate representation in stage I disease compared with men $(71.4 \%$ vs $58.6 \%, P<.001)$ (Table 1).

With regard to adenocarcinoma, which was the most frequent histology $(n=2054,74.2 \%)$, there was a significant difference in pathologic features between men and women. There were more well-differentiated tumors $(P<.001)$ in women but more lymphatic $(P=.011)$ or vascular invasion $(P<.001)$ in men (Table 2). There were $844 \mathrm{~T} 1$ adenocarcinomas with a greatest dimension of less than $2 \mathrm{~cm}$, and information regarding Noguchi's types was available in 604 cases $(71.6 \%)$. Women had more Noguchi's type A or B $(P=.000)$ and less Noguchi's type $\mathrm{D}, \mathrm{E}$, or $\mathrm{F}(P=.000)$ (Figure 1).

\section{Survival Analysis}

Overall 5-year survivals for men and women were $70 \%$ and $81 \%$, respectively (Figure 2), and there was a statistically significant gender difference in survival $(P<.001)$. In adenocarcinoma, the overall 5-year survival was $84 \%$ for women $(\mathrm{n}=1012)$ and $75 \%$ for men $(\mathrm{n}=1042)(P<$ $.001)$. However, there was no significant gender difference in survival in non-adenocarcinoma $(P=.299)$ (Figure 3). When the patients were divided into subsets according to the combination of histology and pathologic stage, overall
TABLE 1. Characteristics of patients $(n=2770)$ with resected nonsmall cell lung cancer

\begin{tabular}{|c|c|c|c|}
\hline & $\begin{array}{c}\text { Men } \\
(n=1689)\end{array}$ & $\begin{array}{c}\text { Women } \\
(\mathbf{n}=\mathbf{1 0 8 1})\end{array}$ & $\begin{array}{c}P \\
\text { value }\end{array}$ \\
\hline Age $(y)$ & 64.8 & 62.8 & $<.001$ \\
\hline $\mathrm{FEV}_{1.0}(\%)$ & $76.8 \pm 21.6$ & $82.5 \pm 12.7$ & .33 \\
\hline Ever-smoker (\%) & 77.5 & 22 & $<.001$ \\
\hline Elevated CEA level $^{\mathrm{a}}(\%)$ & 28.2 & 21 & $<.001$ \\
\hline \multicolumn{4}{|l|}{ Operative procedures } \\
\hline $\begin{array}{r}\text { Wedge resection }+ \\
\text { Segmentectomy }\end{array}$ & $189(11.2 \%)$ & $134(12.4 \%)$ & .877 \\
\hline Lobectomy & $1381(81.8 \%)$ & $921(85.2 \%)$ & .38 \\
\hline Pneumonectomy & $119(7.0 \%)$ & $26(2.4 \%)$ & .665 \\
\hline \multicolumn{4}{|l|}{ Morbidity/mortality } \\
\hline Mortality & $11(0.65 \%)$ & $6(0.65 \%)$ & .392 \\
\hline Serious complications ${ }^{\mathrm{b}}$ & $11(0.7 \%)$ & $5(0.5 \%)$ & .523 \\
\hline Empyema with or without BPF & $34(2 \%)$ & $4(0.4 \%)$ & $<.001$ \\
\hline \multicolumn{4}{|l|}{ Histology } \\
\hline Adenocarcinoma & $1042(61.7 \%)$ & $1012(93.6 \%)$ & $<.001$ \\
\hline Squamous cell carcinoma & $511(30.3 \%)$ & $44(4.1 \%)$ & $<.001$ \\
\hline Large cell carcinoma & $97(5.7 \%)$ & $10(0.9 \%)$ & $<.001$ \\
\hline Others & $39(2.3 \%)$ & $15(1.4 \%)$ & .077 \\
\hline \multicolumn{4}{|l|}{ Pathologic stage } \\
\hline CIS & $2(0.1 \%)$ & $1(0.1 \%)$ & \\
\hline p stage I & $990(58.6 \%)$ & $772(71.4 \%)$ & $<.001$ \\
\hline p stage II & $320(18.9 \%)$ & $111(10.3 \%)$ & $<.001$ \\
\hline p stage III & $361(21.4 \%)$ & $190(17.6 \%)$ & .014 \\
\hline p stage IV & $16(1 \%)$ & $7(0.6 \%)$ & .385 \\
\hline
\end{tabular}

$F E V$, Forced expiratory volume; $C E A$, carcinoembryonic antigen; $B P F$, bronchopleu-

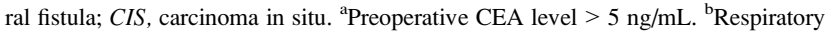
complications that required ventilator assistance, cerebrovascular accident, congestive heart failure, or acute myocardial infarction.

5-year survival of women was significantly better than that of men in pathologic stage I $(95 \%$ vs $87 \%, P<.001)$ and pathologic stage II or higher $(58 \%$ vs $51 \%, P=.017)$ within adenocarcinoma (Figures 4, $A$ and $5, A$ ). On the other hand, there was no significant gender difference in survival in pathologic stage I $(79 \%$ in men vs $74 \%$ in women, $P=$ $.313)$ or pathologic stage II or higher $(50 \%$ in men vs $48 \%$ in women, $P=.770$ ) within non-adenocarcinoma (Figures $4, B$ and $5, B$ ).

TABLE 2. Pathologic features of adenocarcinoma according to gender status $(n=2054)$

\begin{tabular}{lccc}
\hline & Male $(\mathbf{n}=\mathbf{1 0 4 2})$ & Female $(\mathbf{n}=\mathbf{1 0 1 2})$ & $\boldsymbol{P}$ value \\
\hline Differentiation & & & \\
$\quad$ Well & $524(50.3 \%)$ & $678(67 \%)$ & $<.001$ \\
$\quad$ Moderate & $345(33.1 \%)$ & $283(28 \%)$ & .11 \\
$\quad$ Poor & $173(16.6 \%)$ & $51(5 \%)$ & $<.001$ \\
Lymphatic invasion & & & \\
$\quad$ Present & $489(46.9 \%)$ & $396(39.1 \%)$ & .011 \\
$\quad$ Vascular invasion & & & \\
$\quad$ Present & $510(48.9 \%)$ & $369(36.5 \%)$ & $<.001$ \\
\hline
\end{tabular}



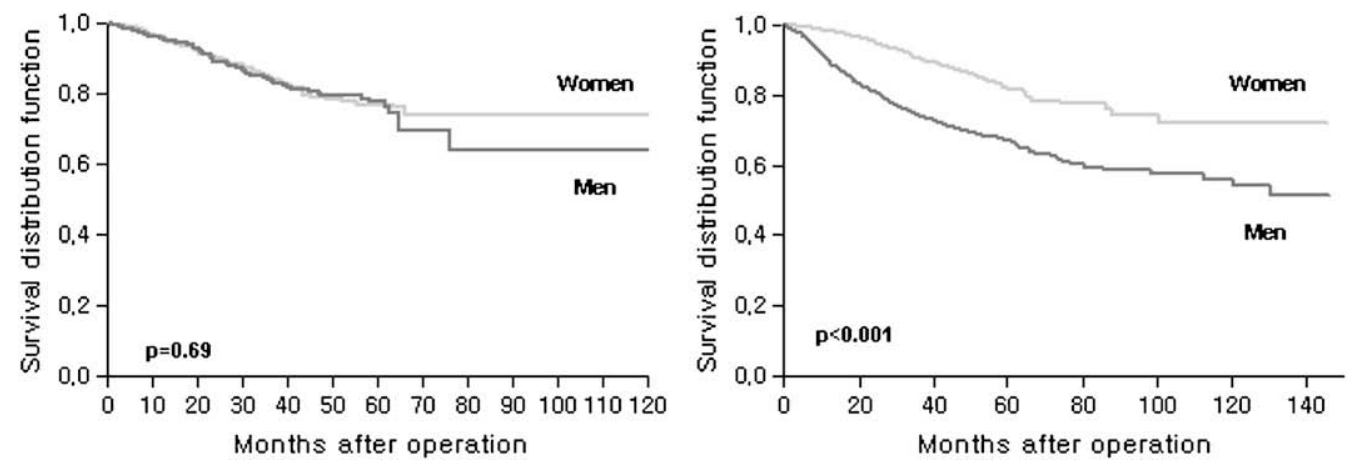

FIGURE 1. Distribution of Noguchi's type for smaller adenocarcinoma according to gender. There are significantly more Noguchi's type A or B in women and more Noguchi's type D, E, or F in men.

\section{Propensity Score Matching}

The distribution of characteristics of propensity scorematched gender pairs $(n=539)$ were summarized in Table 3 . They were well-matched gender pairs without significant difference in clinical characteristics. There was no significant gender difference in survival in propensity scorematched gender pairs $(P=.69)$ (Figure 6).

\section{DISCUSSION}

We observed a significant survival difference between men and women without notable differences in background, such as preoperative pulmonary function, type of operation procedure, or operative mortality. Although the better survival of women in the present study is consistent with several previous reports (Table 4), it can be inferred from the survival analysis of propensity score-matched gender pairs that gender is a marker of a certain risk group with different tumorigenesis rather than an independent prognostic indicator.

Several factors can be considered to be interrelated with the better survival of women: 1) histopathology; 2) internal environment, such as hormonal or genetic status; and 3) innate demographic characteristics or artifactual factors. It has been reported that the impact of tumor histology on survival is unclear. Alexiou and colleagues ${ }^{13}$ showed that squamous cell type was an independent favorable predictor of survival, whereas others have shown no survival difference based on the cell type. ${ }^{14}$ Women showed a significantly larger proportion of well-differentiated type adenocarcinoma (Table 2) and Noguchi's classification A or B (Figure 1). A high degree of differentiation provides a relative survival advantage, ${ }^{15}$ and survival is significantly longer even in patients after recurrence with well-differentiated tumors than in those with moderately or poorly differentiated tumors. ${ }^{16}$ The degree of differentiation is related to the expression of tumor suppressor gene, such as WW domain-containing oxidoreductase, and the reduced or absent expression of this gene was observed in invasive adenocarcinoma. ${ }^{17}$ These results reflect the notion that the degree of differentiation is related to biological aggressiveness at a genetic level. It is also supported by the report that epidermal growth factor receptor mutation was correlated with subtypes of adenocarcinoma and their histologic grade. ${ }^{18}$ On the basis of the subset analyses according to the histology and survival analysis in propensity score matching, histology is assumed to be one of the factors affecting the gender difference in survival.

The distinctive internal environment of women might be related to their better survival. It has been reported that gender-dependent differences in estrogen receptor alpha and beta expression could contribute to unique phenotypic characteristics of lung cancer in women. ${ }^{19}$ Likewise, parathyroid hormone-related protein, which predicts longer survival in women but not in men, showed a more intense tumor suppression effect in an NSCLC model in female mice because it was regulated negatively by androgen hormone. ${ }^{20}$ Along with hormonal influences, genes such as $p 53^{R 172 H ? g / H}$ $K$-ras ${ }^{L A I / 4}$ have been recognized to be associated with aggressive behavior and even a gender difference in cancerrelated death. ${ }^{21}$

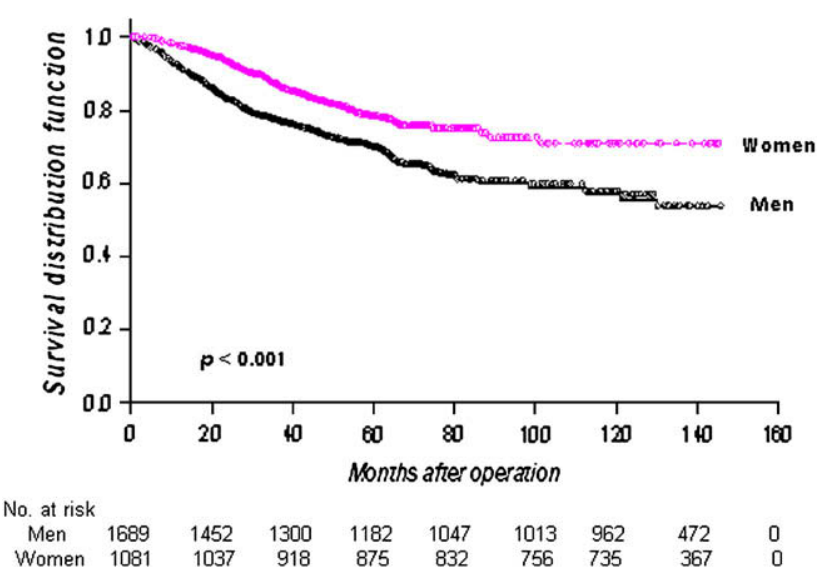

FIGURE 2. Survival curves according to gender. The overall 5-year survival is $81 \%$ for women $(n=1081)$ and $70 \%$ for men $(n=1689)$. Women show significantly better survival than men $(P<.001)$. 


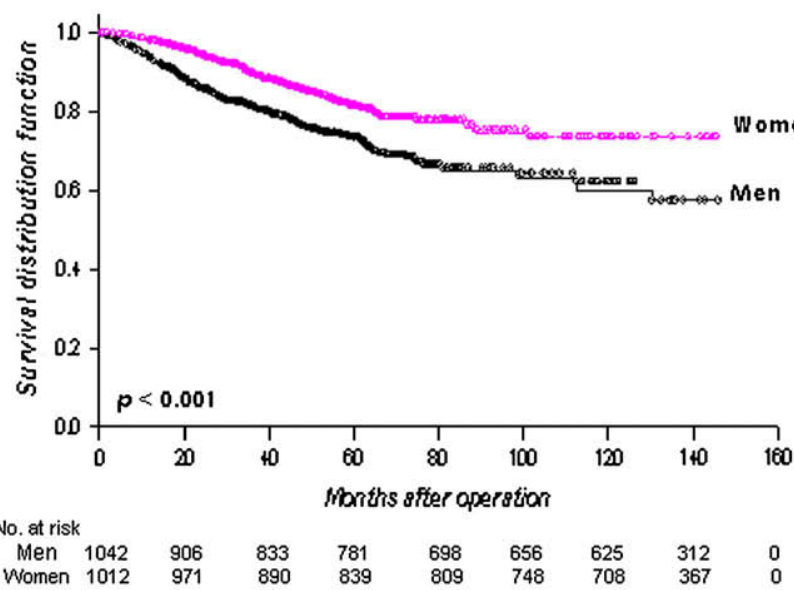

A

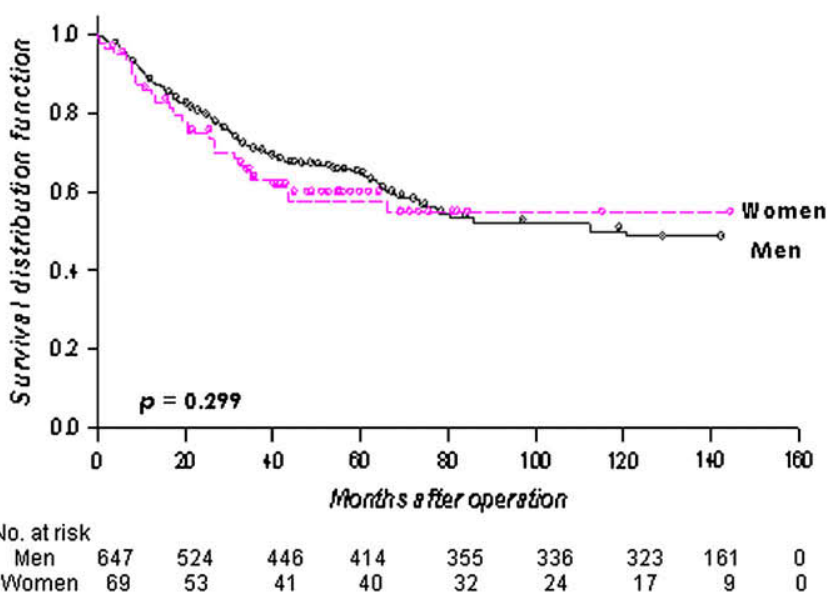

B

FIGURE 3. Survival curves according to gender in adenocarcinoma (A) and non-adenocarcinoma (B). In adenocarcinoma, the overall 5-year survival is $75 \%$ for men $(\mathrm{n}=1042)$ and $84 \%$ for women $(\mathrm{n}=1012)$. This gender difference is significant $(P<.001)$. In non-adenocarcinoma, the overall 5-year survivals of men $(\mathrm{n}=647)$ and women $(\mathrm{n}=69)$ are $64 \%$ and $58 \%$, respectively. This gender difference in survival is not significant $(P=.299)$.

Several artifactual factors might be related to the gender difference in survival. ${ }^{22}$ The demographics of Japan are changing so rapidly that life expectancy is increasing for women. Furthermore, a favorable mix of demographic variables, such as good performance status, more asymptomatic or screen-detected diseases, and fewer comorbidities, might affect the better survival of women, although such information was not available in this study.

One of the most remarkable results of this study is that women show better survival than men even within subsets of the same pathologic stage within adenocarcinoma, but on the other hand no difference was observed in non-adenocarcinoma subsets. One possible explanation for this result is a difference in smoking status. In contrast with non-adenocarcinoma, in most cases, adenocarcinoma in women arises in the absence of the carcinogenic effect of tobacco, or at least under the influence of only secondhand smoke from the spouse or workplace. This could be responsible for the difference in tumorigenesis and pathobiological activity of adenocarcinoma in women. In addition to this difference in smoking status, women are often exposed to different external environments, such as cooking fumes from fuels and oils, household pollutants, and industrial dust. Ko and colleagues ${ }^{23}$ suggested that the frequency of exposure to fumes from cooking oils, when not reduced by an extractor, might be an important factor in lung cancer in nonsmoking women.
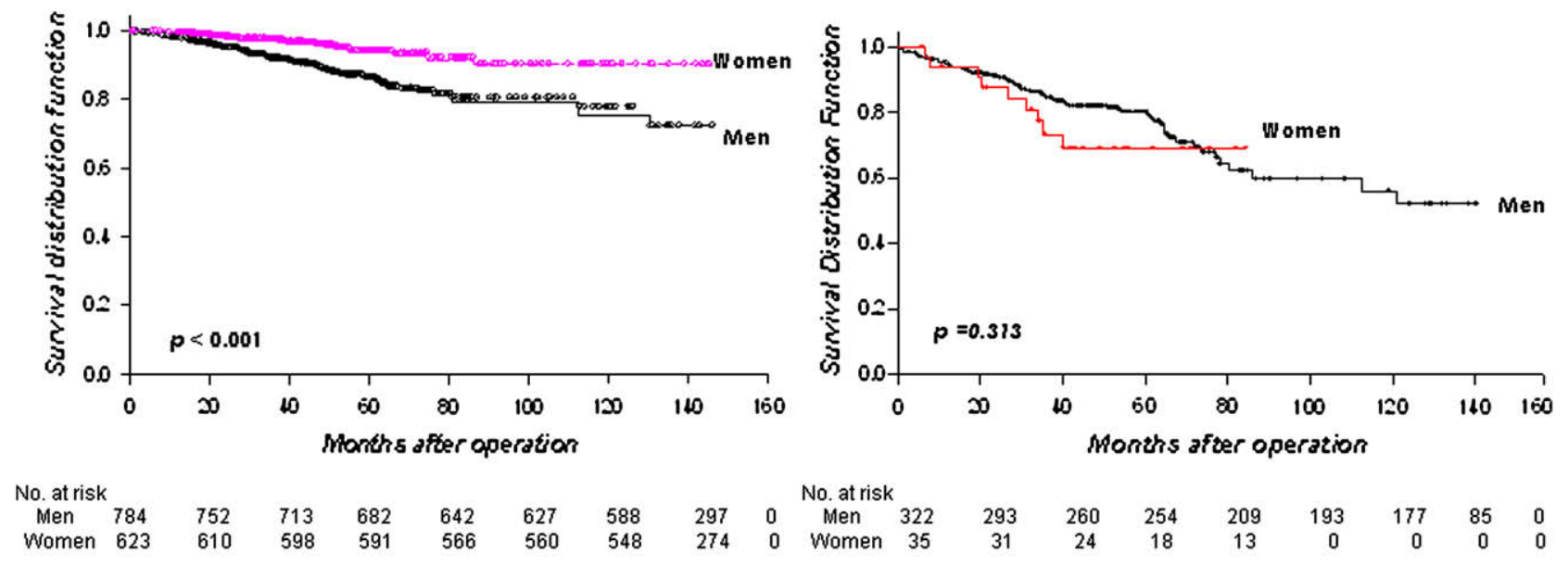

A

B

FIGURE 4. Survival curves according to gender of pathologic stage $I$ in adenocarcinoma (A) and non-adenocarcinoma (B). The overall 5-year survival of pathologic I in adenocarcinoma for women is significantly better than that for men $(95 \% \mathrm{vs} 87 \%, P<.001)$. There is no significant gender difference in survival of pathologic stage I in non-adenocarcinoma ( $79 \%$ vs $74 \%, P=.313)$. 

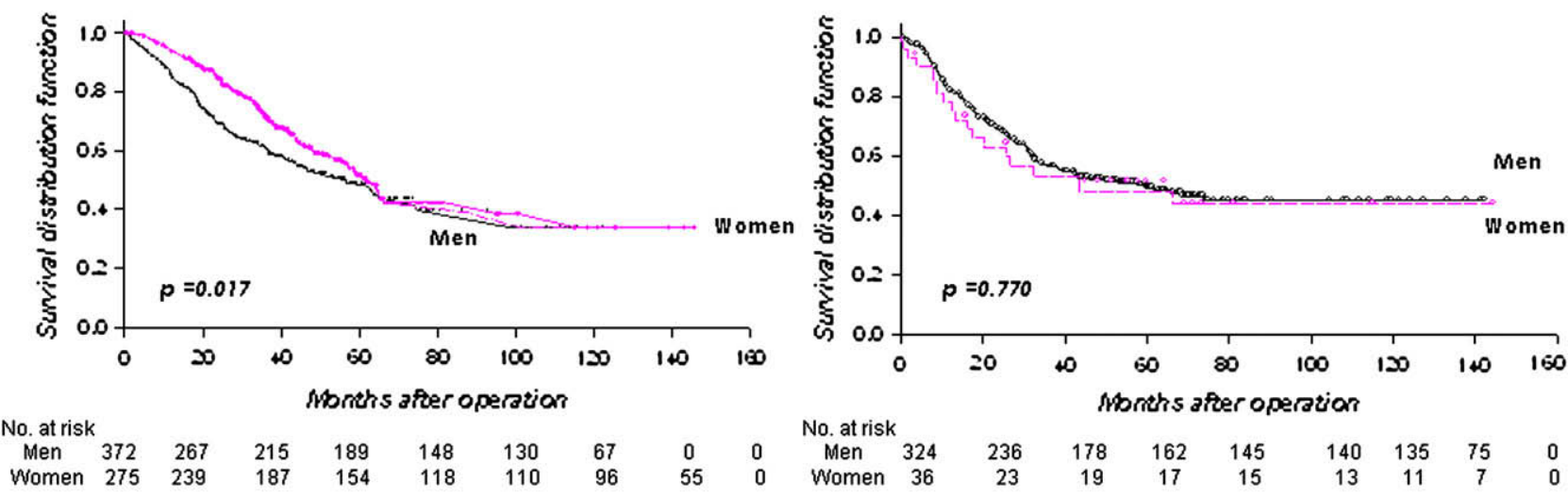

A

B

FIGURE 5. Survival curves according to gender of pathologic stage II or higher in adenocarcinoma (A) and non-adenocarcinoma (B). There is a significant gender difference in survival in the subset of adenocarcinoma (57\% in women, $51 \%$ in men, $P=.017)$, but not in non-adenocarcinoma (50\% in men, $48 \%$ in women, $P=.770$ ).

TABLE 3. Characteristics of propensity-matched gender pairs $(\mathbf{n}=\mathbf{1 0 7 8})$

\begin{tabular}{lccc}
\hline & Men $(\mathbf{n}=\mathbf{5 3 9})$ & Women $(\mathbf{n}=\mathbf{5 3 9})$ & $\boldsymbol{P}$ value \\
\hline Age $(\mathrm{y})$ & 63.4 & 62.8 & .07 \\
Ever-smoker & $259(48.1 \%)$ & $238(44.2 \%)$ & .22 \\
Adenocarcinoma & $448(83.1 \%)$ & $450(83.5 \%)$ & .92 \\
p stage I & $350(64.9 \%)$ & $355(65.9 \%)$ & .78 \\
\hline
\end{tabular}

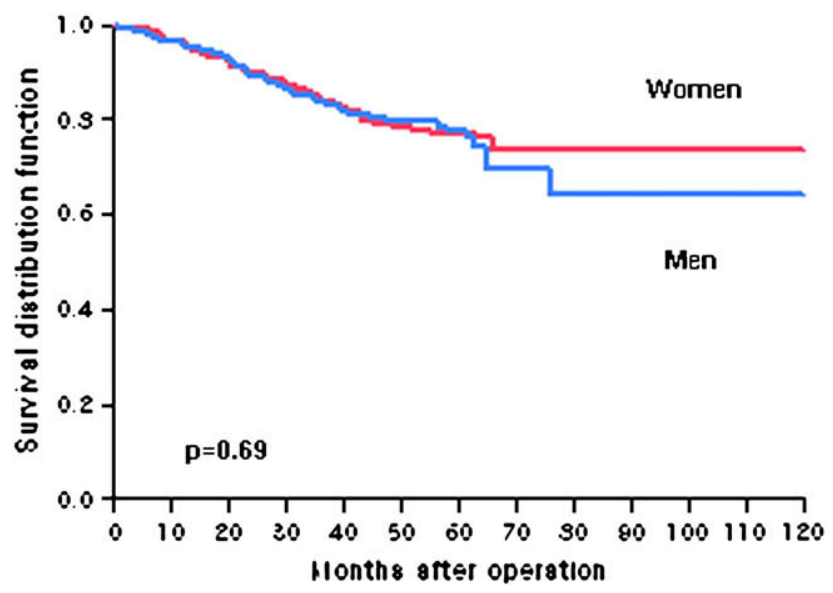

FIGURE 6. Survival curves of propensity score matched-gender pairs. There is no significant gender difference in survival $(P=.69)$.

Complicated interactions in the external environment may underlie the difference in adenocarcinoma in women.

On the basis of the results regarding gender differences in the pathologic features of adenocarcinoma or survival analyses in subsets, adenocarcinoma in women is presumed to have different pathobiologic behaviors from that in men. Genetic polymorphisms, familial susceptibility, and the mutation of specific genes are now being investigated as
TABLE 4. Reports describing a gender difference in survival in lung cancer

\begin{tabular}{|c|c|c|c|c|}
\hline Authors & Year & $\begin{array}{c}\text { Years } \\
\text { analyzed }\end{array}$ & $\begin{array}{c}\text { Gender } \\
\text { difference } \\
\text { in survival }\end{array}$ & Comments \\
\hline $\begin{array}{l}\text { Ferguson and } \\
\text { colleagues }^{1}\end{array}$ & 2000 & 1980-1998 & $P=.006$ & \\
\hline $\begin{array}{l}\text { Alexiou and } \\
\text { colleagues }^{13}\end{array}$ & 2002 & 1990-2000 & $P=.001$ & $\begin{array}{l}\text { Lower operative } \\
\text { mortality in women }\end{array}$ \\
\hline $\begin{array}{l}\text { Cerfolio and } \\
\text { colleagues }^{3}\end{array}$ & 2006 & 1998-2005 & $P<.001$ & $\begin{array}{l}\text { Stages I, II, and } \\
\text { III NSCLC }\end{array}$ \\
\hline $\begin{array}{l}\text { Foegle and } \\
\text { colleagues }^{7}\end{array}$ & 2007 & 1982-1997 & $P=.84$ & \\
\hline $\begin{array}{l}\text { Asamura and } \\
\text { colleagues }^{4}\end{array}$ & 2008 & 1999 & $P=.000$ & \\
\hline
\end{tabular}

possible causes of the biological differences in adenocarcinoma in women. ${ }^{24-26}$ Further investigations are needed on the pathologic and biological nature of adenocarcinoma in women.

\section{CONCLUSIONS}

There is significant gender difference in survival after resection of NSCLC. Women show significantly better overall 5 -year survival than men in all patients and in subsets of adenocarcinoma within the same pathologic stage, but there was no survival advantage of women in propensity-matched gender pairs. The pathobiology in adenocarcinoma in women might be different from that in men.

\section{References}

1. Ferguson MK, Wang J, Hoffman PC, Haraf DJ, Olak J, Masters GA, et al. Sexassociated differences in survival of patients undergoing resection for lung cancer. Ann Thorac Surg. 2000;69:245-50. 
2. Radzikowska E, Glaz P, Roszkowski K. Lung cancer in women: age, smoking, histology, performance status, stage, initial treatment and survival. Populationbased study of 20,561 cases. Ann Oncol. 2002;13:1087-93.

3. Cerfolio RJ, Bryant AS, Scott E, Sharma M, Robert F, Spencer SA, et al. Women with pathologic stage I, II, and III non-small cell lung cancer have better survival than men. Chest. 2006;130:1796-802.

4. Asamura H, Goya T, Koshiishi Y, Sohara Y, Eguchi K, Mori M, et al. A Japanese lung cancer registry study prognosis of 13,010 resected lung cancers. $J$ Thorac Oncol. 2008;3:46-53

5. Goya T, Asamura H, Yoshimura H, Kato H, Shimokata K, Tsuchiya R, et al. Prognosis of 6644 resected non-small cell lung cancers in Japan: a Japanese lung cancer registry study. Lung Cancer. 2005;50:227-34.

6. Hanagiri T, Sugio K, Uramoto H, So T, Ichiki Y, Sugaya M, et al. Gender difference as a prognostic factor in patients undergoing resection of non-small cell lung cancer. Surg Today. 2007;37:546-51.

7. Foegle J, Hedelin G, Lebitasy M, Purohit A, Velten M, Quoix E. Specific features of non-small cell lung cancer in women: a retrospective study of 1738 cases diagnosed in Bas-Rhin between 1982 and 1997. J Thorac Oncol. 2007;2:466-74.

8. Moro D, Nagy-Mignotte H, Bolla M, Colonna M, Brichon P, Brambilla C, et al. Evaluation of survival and prognostic factors in 2,000 broncho-pulmonary cancers registered during 10 years in an oncology department. Bull Cancer. 1997; 84:155-61.

9. Wittekind $\mathrm{CH}$, Henson DE, Hutter RVP, Sobin LH. In: International Union Against Cancer TNM Classification of Malignant Tumors. 6th ed. New York: Wiley-Liss; 1997.

10. Travis WD, Colby TV, Corrin B, Shimosato Y, Brambilla E, Sobin LH. In: Brambilla E, Travis WD, eds. Histological Typing of Lung and Pleural Tumors. 3rd ed. Berlin: Springer-Verlag; 1999. p. 155.

11. Noguchi M, Morikawa A, Kawasaki M, Matsuno Y, Yamada T, Hirohashi S, et al. Small adenocarcinoma of the lung. Cancer. 1995;75:2844-52.

12. Kirklin JW, Barratt-Boyes BG. Generating knowledge from information, data, and analyses. In: Kirklin JW, Barratt-Boyes BG, eds. Cardiac Surgery. New York: Churchill Livingstone; 2003:254-350.

13. Alexiou C, Onyeaka CVP, Beggs D, Akar R, Beggs L, Salama FD, et al. Do women live longer following lung resection for carcinoma? Eur J Cardiothorac Surg. 2002;21:319-25.

14. Mountain CF, Lukeman JM, Hammar SP, Chamberlain DW, Coulser DL, Victor TA, et al. Lung cancer classification: the relationship of disease extent and cell type to survival in a clinical trial population. J Surg Oncol. 1987;35: 147-56.
15. Kadri MA, Dussek JE. Survival and prognosis following resection of primary non-small cell bronchogenic carcinoma. Eur J Cardiothorac Surg. 1991;5: 132-6.

16. Ichinose Y, Yano T, Asoh H, Yokoyama H, Yoshino I, Katsuda Y. Prognostic factors obtained by a pathologic examination in completely resected non-small cell lung cancer. J Thorac Cardiovasc Surg. 1995;110:601-5.

17. Donati V, Fontanini G, Dell'Omodarme M, Prati MC, Nuti S, Lucchi M, et al. WWOX expression in different histologic types and subtypes of non-small cell lung cancer. Clin Cancer Res. 2007;13:884-91.

18. Motoi N, Szoke J, Riely GJ, Seshan VE, Kris MG, Rusch VW, et al. Lung adenocarcinoma: modification of the 2004 WHO mixed subtype to include the major histologic subtype suggests correlations between papillary and micropapillary adenocarcinoma subtypes, EGFR mutations and gene expression analysis. Am J Surg Pathol. 2008;32:810-27.

19. Fasco MJ, Hurteau GJ, Spivack SD. Gender-dependent expression of alpha and beta estrogen receptors in human nontumor and tumor lung tissue. Mol Cell Endocrinol. 2002;188:125-40.

20. Montgrain PR, Quintana R, Rascon Y, Burton DW, Deftos LJ, Casillas A, et al. Parathyroid hormone-related protein varies with sex and androgen status in non-small cell lung cancer. Cancer. 2007;110:1313-20.

21. Zheng S, El-Naggar AK, Kim ES, Kurie JM, Lozano G. A genetic mouse model for metastatic lung cancer with gender differences in survival. Oncogene. 2007; 26:6896-904.

22. Albain KS, Crowley JJ, LeBlanc M, Livingston RB. Survival determinants in extensive-stage non-small cell lung cancer: The Southwest Oncology Group experience. J Clin Oncol. 1991;9:1618-26.

23. Ko Y, Lee C, Chen M, Huang C, Chang W, Lin H, et al. Risk factors for primary lung cancer among non-smoking women in Taiwan. Int J Epidemiol. 1997;26: 24-31.

24. Wu AH, Fontham ETH, Reynolds P, Greenberg RS, Buffler P, Liff J, et al. Family history of cancer and risk of lung cancer among lifetime nonsmoking women in the United States. Am J Epidemiol. 1996;143:535-42.

25. Kiyohara C, Wakai K, Mikami H, Sido K, Ando M, Ohno Y. Risk modification by CYP1A1 and GSTM1 polymorphisms in the association of environmental tobacco smoke and lung cancer: a case-control study in Japanese nonsmoking women. Int J Cancer. 2003;107:139-44.

26. Lynch TJ, Bell DW, Sordella R, Gurubhagavatula S, Okimoto RA, Brannigan BW, et al. Activating mutations in epidermal growth factor receptor underlying responsiveness of non-small cell lung cancer to gefitinib. $N$ Engl J Med. 2004;350:2129-39. 